\title{
Sobre historiografía americanista y un caballero de la hispanidad: Carlos Pereyra en España (1916-1942)
}

\author{
por \\ Priscila Pilatowsky Goñi ${ }^{1}$ \\ El Colegio de México
}

«El hombre de nivel común no se arroja a los grandes peligros sino bajo el dominio de una voluntad subyugadora» ${ }^{2}$.

«La historia es presencia de almas, no solamente la rememoración externa de hechos materiales» ${ }^{3}$.

El presente artículo analiza los últimos años del mexicano Carlos Pereyra en España (1916 a 1942). Nuestro objetivo es comprender las estrategias por las que este personaje se incorporó dentro de la vida cultural española, convirtiéndose en uno de los americanistas más destacados. Desde metodologías de la historia intelectual, revisamos su trayectoria laboral, posiciones politicas, relaciones personales, escritura, y su participación en eventos culturales. Las fuentes incluyen biografias, revistas, periódicos, y una bibliografia que incluye la obra de este autor.

PAlABRAS ClaVE: hispanoamericanismo; americanismo; hispanidad; antiimperialismo; historiografia; historia intelectual; redes intelectuales.

Cómo citar este artículo / Citation: Pilatowsky Goñi, Priscila, "Sobre historiografía americanista y un caballero de la hispanidad: Carlos Pereyra en España (1916-1942)", Revista de Indias, LXXVIII/273 (Madrid, 2018): 561-592. https://doi.org/10.3989/revindias.2018.017.

\footnotetext{
1 ppilatowsky@colmex.mx, ORCID iD: https://orcid.org/0000-0001-6610-2673.

2 Pereyra, 1986: 64.

3 Citado por Acevedo, 1970-1971: 12.
} de uso y distribución Creative Commons Reconocimiento 4.0 Internacional (CC BY 4.0). 


\section{INTRODUCCIÓN}

Carlos Pereyra es figura señera de la historiografía americanista. Hombre de múltiples facetas, fue paladín del ensayo antiimperialista, crítico de la revolución mexicana y entusiasta franquista. Sus profesiones: abogado, profesor, escritor, administrador público y diplomático. Lo recordamos como el positivista, el polígrafo, el polemista, el científico de buena pluma y mejor honestidad, el galardonado con la cruz de Isabel la Católica. Ante su personalidad compleja, los historiadores Andrés Kozel y Sandra Montiel propusieron la expresión «ecuación Pereyra» como aproximación descriptiva de su versatilidad laboral, actitud polémica y variopintos aportes historiográficos ${ }^{4}$.

El jesuita José Bravo Ugarte llamó a este mexicano el «pensador de la hispanoamericanidad» ${ }^{5}$. Otros convienen en llamarlo partidario del «unionismo americano ${ }^{6}$. Sin embargo, sus guiños con el tradicionalismo español y sus críticas a la revolución mexicana le pasaron una factura injusta, de modo que se identifica también - sobre todo en México - como un «reaccionario», un «conservador». El historiador Eric Lobjeois lo dispuso en su repertorio de intelectuales de derecha — junto a Alfonso Junco y José Vasconcelos_-7, mientras que el escritor Andrés Iduarte habló del «brillante reaccionario Carlos Pereyra» ${ }^{8}$. Este abanico de apelativos nos lleva a conceder razón al biógrafo Martín Quirarte, quien opina: «para Pereyra no ha existido crítica serena, se le admira o se le odia, se le acepta o se le condena sin apelación (...). Y lo más grave es que admiradores y detractores han contribuido a falsificarlo»» ${ }^{9}$.

De todas las dimensiones fascinantes en la vida de Pereyra quisiéramos recordar su estancia en España, que inició en 1916 y finalizó en 1942, año de su muerte. Ahí publicó manuscritos que posiblemente había trabajado durante sus labores diplomáticas en los Estados Unidos. España lo distanció de los

${ }^{4}$ Con la expresión «ecuación Pereyra», Kozel y Montiel se refieren a un intelectual mutable y complejo. Describen a Pereyra como un «hombre de frontera, próximo al positivismo y a Justo Sierra (...). Carlos Pereyra crítico de la doctrina Monroe (...); distante de Francisco Madero, de Venustiano Carranza, de Pancho Villa, de Plutarco Elías Calles y de la Revolución mexicana en general; Carlos Pereyra emblema del hispanoamericanismo antiimperialista; Carlos Pereyra autor de El mito de Monroe; Carlos Pereyra ¿fugazmente marxista o filomarxista?». Kozel y Montiel: 2012: 70-71.

5 Bravo Ugarte, 1945: 231.

6 Cagiao, Rey y Pérez, 2007: 314.

7 Lobjeois, 2001: 163-198.

8 Iduarte, 1951: 38.

9 Quirarte, 1952: 3. 
altercados del México revolucionario. En España disfrutó un período de reflexión y productividad, aunque también padeció los infortunios de la guerra civil. El acceso a archivos y bibliotecas españoles le permitieron cerrar tareas pendientes. En poco tiempo fue cavando en la historia de la península, y más aún, en la memoria de toda la región hispanoamericana. Sus trabajos vitalizaron el interés por las cosas de América y fueron caros a una España en búsqueda de recursos ideológicos para reforzar el nacionalismo. Por lo tanto, Pereyra recibió homenajes, tanto en vida como después de ella. Ángel Dotor, otro de sus biógrafos - y uno de sus más grandes admiradores - lo llamó «el autor más representativo de la hispanidad» ${ }^{10}$.

El presente artículo consulta biografías, periódicos, revistas, memorias, reseñas a sus libros, esquelas, y la obra personal de Pereyra, para observar su integración en las instituciones y en la vida cultural española. Acudiendo a metodologías que podrían identificarse con la historia intelectual, examinamos su trayectoria laboral, posturas políticas, relaciones, publicaciones, participación en eventos académicos y su escritura. Sus biografías pecan de cierta antigüedad ${ }^{11}$. En ellas advertimos un tono apologético y cierta oscuridad en el manejo de fuentes. Pero no pierden valor como ventana para mirar el camino intelectual de nuestro personaje. Cotejadas con otras fuentes, informan de su trayectoria personal, sus actitudes, aficiones, y relatos sobre algunos eventos desafortunados de su vida. Un método de la presente investigación consiste en ir registrando las transformaciones en la escritura de Pereyra en relación con su trama biográfica. Para lograrlo, acudimos también a la historiografía del siglo XX español, especialmente la relativa al hispanoamericanismo de fines del siglo XIX y principios del XX.

Nuestra vía de acceso a la prensa es digital, siendo de gran utilidad la Biblioteca Virtual de Prensa Histórica y la Hemeroteca Digital de la Biblioteca Nacional de España. Ambos portales permiten buscar palabras en cualquier periódico digitalizado. Por la palabra «Carlos Pereyra» brotan textos de todo género: comentarios sobre sus conferencias, participación en eventos culturales, publicidad de sus libros, extractos de sus escritos. Los resultados son sugerentes para identificar los medios de comunicación que estaban interesados en él, los eventos a los que acudía, y las personas que conocía. Además, el recurso electrónico ofrece un acceso posible a la recepción de su obra.

10 Dotor, 1948: 9.

11 La biografía más reciente es la de Acevedo, 1986. También Dotor, 1948. Quirarte, 1952. Garrido, 1969. Otro escritos biográficos más breves son los textos de Aguayo Spencer, 1948. Bravo Ugarte, 1945. Y los prólogos y notas de Manuel González Ramírez en las Obras completas de Pereyra, 1959. 
En la prensa - y también en las biografías - convergen opiniones de periodistas, escritores, artistas, editores, políticos e individuos de diversas convicciones. Esta polifonía no sólo es testimonio de la recepción a la obra de Pereyra, sino también de los temas predilectos en España sobre América. Descubre los valores, los puntos candentes, los tabúes y cuentas pendientes. Así, la intención de estas notas es dar un primer paso en la elaboración de una biografía de Carlos Pereyra, y en la medida en que las fuentes lo permitan, conocer lo que el historiador Jacques Revel llamó un «momento historiográfico» ${ }^{12}$.

\section{BREVES ANTECEDENTES BIOGRÁFICO-INTELECTUALES}

Carlos Pereyra nació en Saltillo Coahuila, México, en el año de 1871. A principios del siglo XX estudió derecho. Fue Defensor de Oficio y agente del Ministerio Público. En 1904 arrancó su ejercicio académico como profesor de la Escuela Nacional Preparatoria (EPN), donde reveló sus dotes de polemista en un altercado contra Francisco Bulnes, historiador consagrado del porfiriato. Este altercado se inició cuando Pereyra criticó presuntos juicios y lagunas informativas de Bulnes en Las grandes mentiras de la historia. Los vehículos de las críticas de Pereyra fueron los libros De Barradas a Baudin y Juárez discutido como dictador y estadista (ambos de 1904) ${ }^{13}$. Desde entonces, este autor revelaba ser devoto de la precisión y el conocimiento. Mostraba ser buen polemista, pero sobre todo, un buen investigador.

Pereyra se entrenó como historiador en el principal núcleo de experimentación de la historia positivista en México, que podría identificarse precisamente con la ENP y con Justo Sierra ${ }^{14}$. Cabe recordar que una de las propuestas más relevantes del equipo de Sierra fue la enseñanza de la historia ${ }^{15}$. Los años finales del siglo XIX vieron surgir obras como México a través de los

12 Revel, 2005.

13 Ambos libros critican el trabajo de Francisco Bulnes. Juárez discutido incluía las observaciones de Justo Sierra y de su equipo hacia el libro de Bulnes, que al parecer estaba plagado de errores. Dumas, 1992: 167. De Barradas a Baudin constituye también un juicio al libro Las grandes mentiras de nuestra historia, de Bulnes. Pereyra ya asienta aquí su mirada de historiador. Acusa a Bulnes de «orador y polemista», y descalificaba a otros historiadores por lanzar una serie de comentarios «ditirámbicos», con «escasa talla analítica» sobre varios asuntos del país. Pereyra, 1904a: 3.

14 Para mayores detalles sobre la influencia de las filosofías positivistas en los intelectuales mexicanos, véase Hale, 1991.

15 Hale, 1991: 277-278. 
siglos (1884), de Vicente Riva Palacio; y Sierra estaba preparando varios textos sobre historia antigua que derivarían en la publicación de México, su evolución social (1902) ${ }^{16}$. Pereyra redactó su Historia del pueblo mexicano (1906), sus Lecturas históricas mexicanas y La conquista del Anáhuac (1906). Es posible que la influencia del positivismo en la historiografía mexicana haya sido inspirada por Rafael Altamira, quien visitó varias instituciones en Méxi$\mathrm{co}^{17}$. De hecho, Pereyra parecía haber tenido una buena relación con Altamira aún antes de establecerse en España ${ }^{18}$.

En 1908, el coahuilense dio un giro temático con su libro La doctrina de Monroe, un primer esbozo sobre la política estadounidense ${ }^{19}$. Sin embargo, las opiniones que expresó en este texto se fueron transformando luego de que ocupara la Secretaría de la embajada de México en Washington. Suponemos que este cargo fue el mejor lugar de observación de la trama de intereses expansivos de Estados Unidos hacia América Latina. La doctrina antecedió El mito de Monroe (1917), libro que, como varios autores han señalado, fue el manifiesto con el que Pereyra procuró revelar, y sobre todo prevenir a los hispanoamericanos, de lo que él llamó los «verdaderos» intereses norteamericanos.

Pereyra concilió la diplomacia con la escritura de la historia. Desde el estallido de la revolución mexicana fue ocupando numerosos cargos y recibiendo nombramientos ampulosos. Fue encargado de Negocios en Cuba, miembro de la Academia de Ciencias Sociales y de la Academia Central Mexicana de Jurisprudencia y Legislación. En 1911 ascendió a Primer Secretario de la Embajada de México en Washington y en 1913, a subsecretario de Relaciones Exteriores. Ese año fue activo, ya que también fungió como ministro Plenipotenciario de México en Bélgica y Holanda, miembro del Tribunal Internacional de La Haya y de la Academia Mexicana de la Historia. Según Quirarte, Pereyra dejó las llaves de la embajada de México en Bélgica y se instaló en Suiza ${ }^{20}$. Luego de dos años en Lausana, su siguiente destino fue Madrid.

16 Dumas, 1992: 167.

17 Altamira (2007) dejó testimonio de estos viajes en su libro Mi viaje a América, publicado por primera vez en 1910.

18 Parece que entre Pereyra y Altamira había una relación de amistad. Palmira Vélez cita una correspondencia en la que Pereyra llama a Altamira «mi querido amigo». Vélez, 2007: 234.

19 Siguiendo a Kozel y Montiel (2012), es difícil datar la fecha de publicación de La doctrina de Monroe, pero una fecha admisible es la de 1916, indicada por Acevedo.

${ }^{20}$ Quirarte, 1952: 55. 


\section{BLANCO FombONA Y EL HISPANOAMERICANISMO}

Pereyra llegó a España en $1916^{21}$. Su fama lo había antecedido, puesto que al presentarse con el escritor y editor venezolano Rufino Blanco Fombona, director de la Editorial América, éste se complació en publicar sus trabajos. Fue un encuentro afortunado para un editor resuelto a apoyar a los escritores hispanoamericanos en Europa. Quirarte narra la escena del encuentro y menciona que Blanco dijo al mexicano: «usted dará prestigio a mi editorial» ${ }^{22}$.

La ruta intelectual de Blanco Fombona es igualmente fascinante. Era amigo de los modernistas Rubén Darío, José Enrique Rodo y de buena parte de la intelectualidad española. Desde que Blanco llegó a Madrid, en 1914, se comprometió con la causa bolivariana y con la espiritualidad compartida entre España y América. Eligió el oficio de editor, que lo haría mediador del pensamiento a ambas orillas del Atlántico, y por su extensa producción maravilló. Según Yolanda Segnini, la Editorial América de Blanco produjo, entre los años de 1915 y 1917, unos cien títulos, es decir, casi un libro por semana ${ }^{23}$.

Entre Blanco y Pereyra surgió una relación simbiótica. Compartieron ideales y fueron buenos socios profesionales. Blanco publicó a Pereyra, pero éste último apoyó al editor con reseñas y prólogos de libros que brotaban de Editorial América. Blanco tenía astucia comercial. Conocía la dinámica editorial y las preferencias de los lectores. Sin embargo, es posible que Pereyra haya contribuido en el éxito de la empresa. Segnini cuenta que el mexicano decidió modificar el título de un libro llamado La ilusión americana, por La ilusión yanqui $^{24}$. Este cambio de palabra pudo resultar estratégico para producir efectos tendenciosos y sensacionalistas, así como para capturar lectores anti estadounidenses. Segnini no lo dice, pero podríamos asegurar que el autor del libro era Eduardo Prado.

Blanco sabía aprovechar el interés de España por las cosas de América. Tal interés no era nuevo ni coyuntural. Según Palmira Vélez, ya era «una necesidad desde el mismo momento en que las nuevas tierras descubiertas fueron anexionadas a la Corona» ${ }^{25}$. De esta motivación germinó —en sucesivas réplicas - el movimiento «hispanoamericanista», definido por Aimer Granados como una «una corriente de pensamiento que en algún momento de la primera mitad del siglo XIX empezó a preocuparse por consolidar un proyec-

\footnotetext{
21 Acevedo, 1986: 23.

22 Quirarte, 1952: 60.

23 Segnini, 2000: 62.

24 Ibidem: 82.

25 Vélez, 2007: 48.
} 
to cultural amplio que involucrara a España y a sus antiguas colonias en América» ${ }^{26}$.

Cuando Pereyra se instaló en la península ibérica, en la segunda mitad del siglo XX, España presenciaba una revitalización de aquel movimiento hispanoamericanista - que Blanco Fombona encarna-, con ciertos ecos filosóficos de la generación del $98^{27}$. De hecho, en las primeras décadas del siglo XX seguían activas algunas instituciones americanistas fundadas a fines del siglo XIX, de las cuales cabe citar a la Unión Iberoamericana (1885), la Universidad de Oviedo, así como algunos centros de intercambio académico como la Junta para la Ampliación de Estudios (1907) y el Ateneo español de Madrid $^{28}$. Los viajes de Rafael Altamira y Adolfo Posada habían sido claves para estrechar convenios educativos y culturales en la región hispanoamericana $^{29}$. Varios hispanoamericanos publicaban en revistas académicas españolas, entre las que cabe citar a la Revista de Cultura Hispanoamericana, de la Universidad de Santiago de Compostela, a la que Pereyra envió contribuciones $^{30}$. Así, el reencuentro entre España y América de principios del siglo XX tenía una larga historia institucional y una de sus mejores expresiones visibles eran las redes intelectuales.

Más allá de la esfera intelectual, entre los años de 1920 y 1921, la diplomacia española abría sus horizontes hacia América. Juan Carlos Pereira Castañares explica cómo desde el fin de la primera guerra mundial, en España surgió la necesidad de activar la economía y de establecer relaciones comerciales $^{31}$. Por su parte, la opinión pública española era favorable a nuevos

26 Granados, 2005: 17.

27 Se conoce como «generación del 98» a un conjunto de escritores españoles unidos por un recuerdo depresivo de la derrota de España en la guerra con Estados Unidos de 1898. Entre los más destacados cabe nombrar a Miguel de Unamuno, Ángel Ganivet, Ramiro de Maeztu, Pío Baroja, Azorín, Vicente Blasco Ibáñez y Ramón María del Valle Inclán. Existe una bibliografía muy amplia sobre esta generación. Desde la historia de las emociones, cabe citar el reciente trabajo de Krauel, 2013. También es pertinente mencionar a Shaw, 1985 y a Laín Entralgo, 2005.

28 Labra, 1906.

29 Altamira realizó viajes a diversos países americanos, incluyendo México, Cuba, Argentina, Chile, Perú y Estados Unidos. En estos viajes promovió los intercambios de profesores universitarios y material escolar, la concesión de becas, la creación de escuelas para inmigrantes en América, las delegaciones españolas en congresos de estudiantes latinoamericanos, así como la creación de una sección hispanoamericanista en la Universidad de Oviedo. Vélez, 2007: 169. Sobre el programa de Altamira, véase su escrito autobiográfico Mi viaje a Améri$c a$. Sobre la complejidad del movimiento hispanoamericanista, véase Granados, 2005.

30 Cagiao, Rey y Pérez, 2007: 309-319.

31 Pereira Castañares, 1986: 137-138. 
convenios con Hispanoamérica con el objeto de llevar a España al grupo de potencias de primer orden ${ }^{32}$. El gobierno de Miguel Primo de Rivera (19231930) aumentó el presupuesto a las agencias diplomáticas, multiplicó a los miembros del cuerpo consular, organizó congresos, y eventos de gran envergadura como la Exposición Iberoamericana de Sevilla, en 1929. En suma, Pereyra descubrió a una España proyectándose hacia una nueva fase hispanoamericanista y él habría de convertirse en una pieza clave de ella.

\section{EL ENSAYO ANTIIMPERIALISTA}

Los primeros trabajos publicados por Pereyra en la Editorial América fueron El mito de Monroe (1916), Hernán Cortés y la epopeya de Anáhuac (1916), Bolivar y Washington (1917) y El crimen de Woodrow Wilson (1917). Parece que Pereyra había redactado estos textos en Bélgica y Suiza ${ }^{33}$, —y esto se verifica en el colofón de algunos- Lo que no deja de sorprendernos es el tiempo tan corto que transcurrió entre la llegada de nuestro personaje, y la publicación, distribución y formación de una cálida recepción de sus libros.

El mito de Monroe - secuela de La doctrina de Monroe y, en consecuencia, un texto más maduro- es una compilación de ensayos en torno a la geopolítica estadounidense y sobre el origen de la doctrina conocida con ese apellido. El libro es fruto de la experiencia diplomática de Pereyra y de su inmersión en los archivos estadounidenses, puesto que analiza correspondencia privada, comentarios, discursos, memorias, notas y fuentes oficiales de otra naturaleza. La más destacada es la comunicación de James Monroe a las Cámaras del Congreso de los Estados Unidos el 2 de diciembre de 1823 - dejando grabado el nombre del presidente en el título de la doctrina-. Nuestro autor interpreta los planes estadounidenses en la trama geopolítica internacional. En esta trama interfieren las opiniones del embajador estadounidenses en Londres Richard Rush y del ministro de exteriores británico George Canning. Pereyra procura escudriñar en los intereses ocultos de los políticos norteamericanos, sin dejar de exponer sus propios juicios. Su mensaje final podría resumirse en la frase: «La doctrina Monroe es una realidad flamante: un mito que sirve de envoltura a este hecho natural: las ambiciones de un pueblo fuerte que pretende ejercer su hegemonía sobre un grupo de

\footnotetext{
32 Ibidem: 139.

33 Por ejemplo, Acevedo, 1986: 28.
} 
pueblos débiles dando a la dominación las apariencias hipócritas del desinterés y de la benevolencia» ${ }^{34}$.

No siempre basta un análisis documental para conjurar las posturas políticas. En ocasiones, la cientificidad ayuda a reforzarlas. El apego al documento en El mito confiere a Pereyra una autoridad poco asequible a los ensayistas latinoamericanos de su tiempo. Sin embargo, su escritura en El mito y en otros ensayos relacionados con los Estados Unidos (por ejemplo: Texas, La primera desmembración de México y El crimen de Woodrow Wilson), esgrime una fuerte denuncia. El mito exige la atención urgente de los hispanoamericanos antes de que los Estados Unidos engulleran a todo el continente. Esta escritura preventiva y ansiosa podría identificarse con géneros de escritura antiimperialista que Alejandra Pita y Carlos Marichal definen como una "prosa vigorosa que suele transmitir un lenguaje político». Esta escritura, según ellos, es propia del «periodismo militante» y por su carácter «combativo y persuasivo» estos autores la llaman «palabra panfletaria» ${ }^{35}$.

A la manera de periodista comprometido, Pereyra se manifestó en sus libros, panfletos, periódicos, revistas, conferencias y charlas públicas. Llegó a escribir personalmente a los representantes de algunos medios. En una ocasión, se dirigió al director del diario español El Imparcial: «El presidente Wilson inicia su apostolado en los momentos de consumar la ocupación de la impotente República Dominicana, la hija primogénita de España en América» ${ }^{36}$.

Aún sus tintes panfletarios, la escritura de Pereyra - autorizada por el uso de fuentes primarias - estremeció a una España donde aún no cicatrizaba la llaga de la guerra de 1898. Más allá, Pereyra pareció dar el tono perfecto de la sensibilidad hispanoamericana tras las constantes intervenciones del país del norte en los asuntos de sus vecinos continentales. En diarios y revistas fluyeron gestos de admiración de parte de escritores, políticos, diplomáticos, periodistas e individuos que no necesariamente formaban parte de los círculos académicos ni culturales. Ángel Dotor, en Carlos Pereyra, legó un inventario muy útil para conocer estas opiniones. En este libro leemos que la revista Estudio de Barcelona destacó la «valentía» de El mito de Monroe. Blanco Fombona llamó a Pereyra «uno de los escritores de lengua española con más preparación y mejor acondicionados para abrir sumario a yanquilandia» ${ }^{37}$. El controvertido marqués decadentista Antonio de Hoyos y Vinent comentó:

\footnotetext{
34 Pereyra, 1916: 53.

35 Pita y Marichal, 2012: 17.

36 Citado por Dotor, 1948: 47.

37 Ibidem: 49.
} 
«Hay que prestar profunda atención a esta obra, dado que su autor es el prestigiado literato don Carlos Pereyra. España está ligada a las repúblicas sudamericanas, no sólo por lazos de amor, sino por grandes bienes materiales y morales, y así ha de escuchar la voz de los que se ocupan de los grandes problemas americanos $»^{38}$.

El debate, periódico de tendencia católica, publicaba avisos de próximas conferencias de Pereyra y comentaba sus escritos, especialmente si se trataban de arengas contra los Estados Unidos. Tras la aparición de El crimen de Woodrow Wilson, este diario atizaba la sensación de peligro: «Mentira. Aún allí donde los gobiernos han secundado la maniobra wilsoniana, los pueblos se agitan y preparan grandes sorpresas, que alarman a los políticos de Washington. Esto se verá claramente en el notable libro El crimen de Woodrow Wilson, del escritor americano Carlos Pereyra» ${ }^{39}$. Un número de ese periódico, del año de 1922, anunciaba la presentación de la conferencia «España y el panamericanismo», en el Ateneo español (Madrid). En una columna leemos que este «orador excelso» había expuesto «el exceso de imperialismo característico de los Estados Unidos, que en boca de no pocos de sus hijos se transforma en esta frase: «América para los americanos» ${ }^{40}$.

Otro diario muy atento hacia Pereyra era el $A B C$. Como el anterior, anunciaba conferencias, publicaciones de libros, y otros eventos en que participaba nuestro personaje. Un "Boletín del día", publicado el 18 de mayo de 1923, recortaba un fragmento de El mito de Monroe originalmente aparecido en la Revue de l'Amerique Latine ${ }^{41}$. Este diario publicó también comentarios —nada breves, por cierto- de Andrés Revesz, admirador del mexicano.

Así, Pereyra estableció una conexión emocional entre el nerviosismo latinoamericano ante el riesgo de invasiones estadounidenses y el resentimiento noventayochista. Sus escritos catalizaron miedos, pero también fuerzas evocativas de la unidad hispanoamericana. Era un escritor de juventudes, lo cual puede palparse en el testimonio del escritor mexicano Andrés Iduarte, otrora su alumno:

Hallábamos en él lo que nuestra edad buscaba: el arrebato glorificador, el feroz panfleto, y todo como sostén de la lucha antiimperialista que daba sentido a nuestras luchas políticas de matiz provinciano ${ }^{42}$.

\footnotetext{
38 Ibidem: 47.

39 El debate, 5 de mayo de 1917.

40 El debate, 1 de marzo de 1922.

$41 A B C, 18$ de mayo de 1923.

42 Iduarte, 1951: 38.
} 


\section{AMERICANISMO E HISTORIOGRAFÍA}

En la década de 1920 Pereyra publicó obras de síntesis de historia hispanoamericana: La huella de los conquistadores (1929), La conquista de las rutas oceánicas (1923), La obra de España en América (1920), Historia de la América española (1920), Breve historia de América (1930) ${ }^{43}$. Cada uno de estos trabajos revela ser producto de un uso extensivo de fuentes, seguramente ubicadas en archivos y bibliotecas españolas: manuscritos antiguos, mapas, memorias, documentos oficiales y una amplia bibliografía.

Según algunos autores, Pereyra experimentó un cambio de perspectiva que puede apreciarse en la diferencia entre sus textos de juventud - críticos a España-, y los que escribió una vez que se estableció en ese país y consultó sus archivos. En ellos pareció comenzar a apreciar lo que llamó la obra «civilizatoria» de España en América. Palmira Vélez es una de las que así lo piensa. En La historiografia americanista en España 1755-1936 escribe: «Hasta su llegada a España, Pereyra había sido crítico con el dominio español, pero tras la misma, el historiador cambió radicalmente. Pereyra se "españolizó"; hizo suyas las propuestas y los criterios del regeneracionismo conservador hispano» ${ }^{44}$. El biógrafo argentino Edberto Óscar Acevedo observó cómo Pereyra transitó hacia posiciones identificadas con lo que se ha llamado la «derecha» española: «Conocemos también que, en gran parte debido a su amor por la verdad en los estudios históricos, pronto evolucionó y, por el más sincero hispanismo, llegaría a las antípodas de aquella ideología: al catolicismo y al tradicionalismo» ${ }^{45}$.

Podríamos matizar este juicio imaginando las condiciones de investigación que Pereyra encontró en España. Tenía a su disposición los amplios repositorios documentales del Archivo General de Indias. Cabe recordar - y de esto también nos habla Vélez-, que la infraestructura del Archivo se fue perfeccionando desde que fuera creado a fines del siglo XVIII. La República pareció haber promovido el buen funcionamiento del archivo para hacer de él un «instrumento valioso al servicio del conocimiento y divulgación de la historia nacional ${ }^{46}$. Así, Pereyra llegó a España en un momento en que existía un depósito documental relativamente organizado - aunque las condiciones de este archivo distaban de asemejarse a las de otros países europeos- y tenía acceso a la consulta de sus documentos. La situación era envidiable para

\footnotetext{
43 Fechas establecidas por Acevedo, 1986: 235.

44 Vélez, 2007: 234.

45 Acevedo, 1986: 41.

46 Vélez, 2007: 107.
} 
cualquier historiador. ¿Cómo no deslumbrarse ante un archivo que resguardaba la historia de ese país? El historiador mexicano Silvio Zavala menciona que Pereyra aprovechó el Archivo, lo que había sido privilegio de pocos, como también lo fue de otro mexicano, el historiador Francisco del Paso y Troncoso. Zavala relata que el coahuilense trabajaba en la biblioteca del Ateneo de Madrid, donde ambos se encontraban y conversaban ${ }^{47}$. En otras palabras, la consulta de archivos y bibliotecas españoles no estaba a la mano de la mayoría de los hispanoamericanos de aquella época. Los enfoques historiográficos de Pereyra deben considerarse a la luz de esta situación peculiar.

Las obras de nuestro autor, producto de sus investigaciones en archivos y bibliotecas españoles, no dejan de sorprender — hasta al historiador actual-, por su erudición, creatividad literaria, y una «relativa» revelación de sus procesos heurísticos - explicaremos más adelante las razones de esa "relatividad»- La conquista de las rutas oceánicas (1923) — por mencionar uno de los libros mejor conocidos-, inicia cual una novela que parte del momento en que Cristóbal Colón buscaba apoyo financiero para su célebre viaje. Algunas frases son de valor literario, por ejemplo: «Todos los viajeros cuentan que una de las emociones más grandes para el que navega por el mar cruzando por la línea ecuatorial, es el cambio de cielo»48; «Durante las navegaciones hacia el sur, las nuevas constelaciones se asociaban acaso para los marinos con representaciones de peligros y desdichas ${ }^{49}$.

A lo largo de ese mismo escrito, Pereyra va fabricando un ambiente, penetra en el talante de las personas, refiere el clima, los recursos materiales y la tecnología. Aparte, ilumina diferentes estratos: la sociedad, de la geografía, la economía y la política. En este sentido, la escritura no tiene forma de narración cronológica. Va paseando entre el acontecimiento, los datos biográficos, la descripción, la sentencia y la narración. Algunos fragmentos son comentarios críticos a los manuscritos que caen en sus manos. Recolecta conclusiones de otros historiadores, cotejándolas con sus propias interpretaciones. De paso, expresa opiniones y va revelando la lógica de su investigación. Sirve de ejemplo su comentario al Libro de las maravillas de Juan de Mandeville. Pereyra nos presenta con el autor y su obra. En adelante, descri-

47 Pereyra, 1986: XII. El mexicano Silvio Zavala también es otro reconocido americanista que estudió en España entre 1931 y 1933. Obtuvo su licenciatura en derecho en la Universidad Central de Madrid y posteriormente grado de doctor. Fue alumno de Rafael Altamira y sus trabajos se enfocaron en las instituciones jurídicas de la Nueva España. Salió a México poco antes de que estallara la guerra civil. Lira, 2012: 14.

48 Pereyra, 1986: 92.

49 Ibidem: 93. 
be la confección física del libro, sus contenidos e ilustraciones. Refiere la trayectoria del manuscrito, sus diferentes ediciones, la circulación y las polémicas en torno a la autoría. Por último, resume la importancia de este título dentro del género de la literatura de viajes.

Otra característica en Pereyra es su interés por las vidas de personajes conocidos, y también por los desconocidos. Por las páginas de La conquista de las rutas oceánicas desfilan misioneros, marinos, lingüistas, etnólogos, científicos, escritores, metalúrgicos, talladores de madera, arquitectos, pintores y escultores. Brotan los nombres de los frailes Alonso de Molina, Toribio de Benavente (Motolinía), Andrés de Olmos y Bernardino de Sahagún. Debido a su predilección por el personaje y por sujetos cuyo protagonismo pasara desapercibido en otras historiografías, Pereyra fue también llamado «sociólogo» ${ }^{50}$. Esta propiedad fue advertida por Ángel Dotor:

En esta serie de volúmenes se habla más de fundadores, de predicadores, de viajeros, de poetas, de arquitectos, de escritores, que de generales y de pronunciamientos; se habla más de los pueblos que de los gobernantes; se habla más de la vida cotidiana que se las ceremonias oficiales y de las fechas consagradas ${ }^{51}$.

Pereyra completa el cuadro social refiriendo los recursos naturales, el estado del conocimiento geográfico, el impacto del clima, la flora y la fauna en el desarrollo industrial y comercial. Leemos sobre la disponibilidad de alimentos y sobre los animales aptos para el trabajo y la conquista. «Es verdad: el caballo y el acero, más bien que la pólvora, establecieron la dominación sobre millones de indígenas americanos. No olvidemos al perro, fiera paralizante; temible caballería ligera del conquistador» ${ }^{52}$. El análisis de la relación entre sociedad-naturaleza y técnica recuerda la metodología de Justo Sierra en México: su evolución social. El conjunto de textos que componen esta obra explican la historia de la formación de la «nación» mexicana en código organicista y evolutivo, enfocando la relación entre el medio geográfico y los seres humanos. La introducción al libro revela sus guiños con la sociología, pero también con subdivisiones de la geografía histórica, como la hidrología y la climatología ${ }^{53}$.

50 Según Palmira Vélez, Pereyra había practicado la sociología en el Ateneo de la Juventud. Véase Vélez, 2007: 233. González Ramírez también llama a Pereyra «sociólogo». Pereyra, 1959.

51 Dotor, 1948: 70.

52 Pereyra, 1986: 150.

53 En la introducción a esta obra se lee: «No significa que nos propongamos hacer un tratado de sociología mexicana, en el sentido estrictamente científico del vocablo (...). De- 
Por otra parte, distinguimos que, en el tiempo en que Pereyra escribía, el gusto de los lectores se decantaba por la vida de los grandes hombres, especialmente si la narración tenía efectos dramáticos. Varios autores escribieron sobre la psicología, personalidad y proezas de conquistadores y militares ilustres. Los orígenes de Cristóbal Colón, Hernán Cortés, Bolívar, San Martín, y otros próceres de las independencias latinoamericanas eran temas frecuentes de la literatura histórica. Este es el caso de obras como la de Martín Astrana y Antonio Ballesteros Beretta, ambas sobre Cristóbal Colón ${ }^{54}$. Pereyra escribió sobre este personaje, sobre Hernán Cortés y sobre otros protagonistas del mundo militar, político y diplomático hispanoamericano. Sus trabajos sobre El pensamiento político de Alberdi y Francisco Solano López y la guerra del Paraguay lo hicieron acreedor a elogios. En un diario de ese país, citado por Dotor leemos que:

Hoy es un hijo es un hijo de México (...) el que recoge la piqueta demoledora y el yunque constructor de Alberdi, para abatir a los falsos ídolos y plasmar el molde en que la historia, por la mano del tiempo, va cuajando el perfil luminoso de los verdaderos representantes de la estirpe ibérica, retoñada en tronco americano ${ }^{55}$.

Podríamos decir que los lectores de Pereyra - y los lectores de literatura histórica en general - tenían afición por los héroes. Quizá para muchos de ellos, era obligación de la historia exaltar las hazañas de los héroes nacionales, pero también resucitar la memoria de hombres poco visibles en el panteón de los ilustres. Así, algunas obras de Pereyra, como El pensamiento político de Alberdi, fueron apreciadas por evocar glorias pasadas de figuras como la del intelectual argentino. Desde este punto de vista, la historia era el brazo justiciero del tribunal de los tiempos.

seamos, con el firme propósito de no adulterar la verdad, mostrar a grandes, pero característicos rasgos, cómo, después de una lenta y penosa gestación, esta Sociedad se desprendió del organismo colonial y fue por un acto de suprema voluntad, y cómo, tras una existencia reglar y tumultuosa, ha llegado a normalizar una labor vital de asimilación de los elementos substanciales de la civilización general sin perder los distintos rasgos de su personalidad», Sierra, 1900: s/p. En otro fragmento del libro se sugiere la influencia de la geografía histórica: «He aquí el programa de la geografía histórica. Después de dar cuenta de los primeros movimientos, de los diversos impulsos, debe asimismo explicar las composiciones y descomposiciones políticas, y sobre el territorio de las ciudades o el teatro de los grandes acontecimientos, tomar por medio de descripciones, a menudo minuciosas, lo que el explorador de la naturaleza con frecuencia desdeña». Sierra, 1900: 8.

54 Astrana, 1929. Ballesteros, 1945.

55 Dotor, 1948: 60. 
Sin embargo, Pereyra matizó las virtudes heroicas de sus personajes. En su descripción del talante de Cristóbal Colón en La conquista de las rutas oceánicas, le atribuyó cualidades y defectos:

Colón era un genio, sin duda, pero lo fue de la voluntad y el entusiasmo, nunca del cálculo y del sistemático movimiento de aproximación hacia lo desconocido (...). Era poeta. No era sabio. Su geografía estaba constituida por dispares y fragmentarias interpretaciones de la ciencia antigua (...) También le faltaba en grado sumo el don de la simpatía. Carácter duro, no era la suya la dureza del hombre poseídos por una idea ${ }^{56}$.

Este enfoque, que parecía evitar la apología y anunciar el carácter humano del personaje, confería credibilidad a Pereyra entre sus lectores. No obstante, al referirse a la personalidad del marino genovés, nuestro autor no explicita el procedimiento historiográfico que le permite sostener que este personaje era un «sabio», o que carecía del «don de la simpatía». Esta indagación en cualidades mentales parece llevar al extremo las posibilidades de la interpretación. Dicho de otra forma, el autor fuerza la información que le ofrecen las fuentes. Es posible que Pereyra echara mano de su propia creatividad para llenar lagunas documentales y para producir efectos literarios. Debido a esta parcialidad, nos referíamos más arriba a la «relatividad» de la heurística. Es pertinente en este sentido la observación de Edberto O. Acevedo:

(Pereyra) aceptaba el hecho por el mero hecho. Pero en seguida, el historiador, sabedor que el pasado requiere algo más y que esta es la gran exigencia de la recreación, de la resurrección, se convertirá en el recreador, aceptando, por punto de partida, que todo hecho del pasado parece poder admitir diferentes resultados, se aleja del simple proceso mecánico de reconstrucción y su método de intelección lo lleva a participar en la vida de los hombres que han sido $^{57}$.

Con estos (y otros) efectos de escritura, Pereyra complació las expectativas de varias clases de lectores y fue ampliamente avalado desde las convenciones historiográficas de su tiempo. La opinión estimaba su habilidad literaria y rigor científico. Un diario de Madrid, citado por Dotor, habló de su «pluma ágil y su estilo vivo y cautivante». La Revista chilena, respecto al libro Humboldt en América, afirmó «La más ligera amenidad corre desde las primeras hasta la última línea, dándole al libro un carácter variado, de obra biográfica y científica, con todo el interés de las peripecias de un libro de viajes» ${ }^{58}$.

\footnotetext{
56 Pereyra, 1986: 56.

57 Acevedo, 1970-1971: 15.

58 Dotor, 1948: 53.
} 
Ángel Dotor también admiró lo que llamó su «estilo sobrio y ponderado; a la vez que pulcro y expresivo, que a lo largo de los tres millares de páginas del libro aparece sin decaer, no dejando de acuciar el interés del lector» ${ }^{59}$. Robert Ricard, traductor de La conquista de las rutas oceánicas al francés, quien escribió en la Revue de l'Amérique Latine, reconoció su «apego a la verdad»: «Esta nueva obra de Pereyra es, verdaderamente, como la de Mandeville (...). Pero el libro de Pereyra sólo trata de realidades y no de fantasías» ${ }^{60}$. Luis Garrido Díaz - ex rector de la Universidad de México, quien le dedicó una biografía - escribió: «Él no ve el pasado con ojos de artista a pesar de las bellas descripciones que a veces hace, pues busca particularmente, no el desfile de imágenes y fechas que permiten formular un juicio histórico, como forma única e integral del conocimiento» ${ }^{61}$.

Pereyra escribía para el gran público. Dio concesiones tanto a quienes buscaban una lectura amena como a los que querían saber «lo que pasó». Silvio Zavala reveló que este autor debió divulgar para sobrevivir: «Pereyra deseó y necesitó para su penosa subsistencia redactar libros que tuvieran lectores; su tarea fue por ello de alta divulgación, pero bien basada en lecturas copiosas en español y otros idiomas modernos» ${ }^{62}$. Quizá haya sido esta voluntad de agradar a un lectorado amplio, por lo que Pereyra manejó recursos estilísticos destinados a los lectores de su tiempo. Reconstruye dramas, crea ambientes, interpreta la voluntad de los protagonistas del pasado. El drama fue, en efecto, una astucia. Él mismo lo explica así: «La obra de divulgación requiere ciertos artificios que la complican y la dificultan. Para popularizar una materia histórica, sobre todo si es tan rica y compleja como la de este libro, hay que apelar por fuerza a la intervención del episodio dramático» ${ }^{63}$.

Como autor bestseller de su época, un factor desconcertante en la escritura es la ausencia de citas, de referencias bibliografías u otras informaciones reveladoras de las fuentes. Un historiador actual afirmará que tal falta induce a desconfianza. Para Pereyra fue un juego literario, un plan premeditado. En La conquista declaró:

Ha sido necesario prescindir de toda cita o documentación comprobatoria, tanto para no robar espacio al texto, como para que el relato vaya por un cauce recto y suave, sin tortuosidades ni cascadas. Sólo así puede darse la impresión virgen de los hechos, aducidos por otra parte con escrúpulos de probidad, que son

\footnotetext{
59 Ibidem: 66.

60 Ibidem: 116.

61 Garrido, 1969: 50.

62 Pereyra, 1929: XIII.

63 Ibidem: 3.
} 
tanto más solícitos cuanto que el autor hace una apelación a la confianza de sus lectores, sin ofrecer pruebas de lo que afirma y discute en otros libros suyos (...) las citas por otra parte, no entran aquí como datos que puedan pesar sobre el espíritu y abrumarlo, sino como estimulantes de la curiosidad ${ }^{64}$.

Este asunto fue advertido por los lectores de su tiempo, quienes no lo consideraron un defecto. Rufino Blanco Fombona opinó: «El procedimiento de todos estos libros es análogo. Huye el autor de presentar el documento, pero se le adivina a través del relato, que es como un blando camino por el que los pies avanzan sin fatiga» ${ }^{65}$. Según él, la estrategia de Pereyra obedecía a un plan literario: «Carlos Pereyra acude a los textos antiguos para proporcionarse elementos de color, y a las anécdotas para mantener atento a su público y para sugerir frecuentemente una enseñanza, o para caracterizar a un personaje» ${ }^{66}$. «A pesar de todo», mencionaba El imparcial de Guatemala, «sus libros están llenos de energía, de pasión contenida, pero no por eso menos cálida y sincera» ${ }^{67}$. En efecto, Pereyra fascinó a sus contemporáneos aun faltándole las citas, su escritura dramatizada y juicios desproporcionados. De hecho, un artículo del diario El Universal de México lo llamó «el mago de la historia» ${ }^{6}$.

\section{LOS AÑOS 1920: ENTRE LA FAMA Y UNA MILITANCIA DIFUSA}

El coahuilense participó en varios eventos del mundo intelectual hispanoamericano, lo cual es testimonio de sus amplias relaciones y apertura mental. Fue orador principal en conmemoraciones, presentaciones de libros, homenajes, incluso si los organizadores profesaban un partidarismo político ajeno al suyo. Encontramos registro de su presencia en un homenaje al escritor costarricense Joaquín García Monje, anunciado en un artículo del diario español republicano La Libertad. Este intelectual fue opositor al gobierno de Federico Tinoco y redactor de la revista Repertorio americano, reconocida por su posición antifascista y republicana. García Monje había militado en movimientos obreristas y comunistas. Su homenaje congregó individuos de lo que podríamos llamar una «izquierda»: Gabriela Mistral, Pablo Neruda, José Mo-

\footnotetext{
64 Idem.

65 Citado por Dotor, 1948: 77.

66 Idem.

67 Ibidem: 79.

68 Ibidem: 110.
} 
reno Villa, Ramón Gómez de la Serna, Luis Recasens y León Felipe ${ }^{69}$. No sabemos si Pereyra compartía los ideales de este grupo. En todo caso, advertimos una vez más su complejidad — recordemos la «ecuación Pereyra»— y la dificultad para comprender sus convicciones políticas.

Pereyra, en sí mismo, recibió homenaje de parte de varias instituciones culturales americanistas. En el año de 1924, la Unión Patriótica de Madrid - fundada por Miguel Primo de Rivera-, organizó una conferencia acerca del historiador Marcelino Menéndez y Pelayo. Según Dotor, en ella se prodigaron sendos elogios a Pereyra, y él aprovechó para promover la escritura de una historia común del mundo hispanoamericano. Otra conferencia que indirectamente rindió honores a Pereyra tuvo lugar el Día de la Raza, el 12 de octubre de 1926, convocada por el Ateneo de Madrid, en el Gran Teatro de Cáceres. Acudieron personalidades de la política y de la administración, como el presidente de la diputación de Badajoz, el Ministro de Instrucción Pública, y miembros del mismo Ateneo. Estaba presente su director, el cubano Rafael María de Labra, uno de los americanistas más reconocidos.

El discurso que Pereyra pronunció en este evento abunda en referencias a las «corrientes de simpatía» entre España y América, y al nuevo mundo descubierto por Colón. De alguna manera, sus palabras llevan un cierto sabor a lo que poco tiempo después se conocería como el pensamiento de la «hispanidad». Ahí expresó: «Es la Extremadura de los conquistadores, de los misioneros, de los justicias, de los adelantados, de los virreyes» ${ }^{70}$. En efecto, el lugar que acogió al evento era simbólico, tanto por la fecha a celebrar como por el significado de Extremadura como tierra de Hernán Cortés. Se conmemoraba la conquista y el papel civilizador de España en América. De hecho, el Ateneo de Cáceres había sido fundado el Día de la Raza del año de 1925. Esta conjunción de signos y evocaciones de la memoria fueron el contexto de un discurso que culminó con las palabras que el gobernador de la ciudad dirigió a Pereyra: "Cuando regreséis a América, decir que un pueblo español, el día 12 de octubre de 1926 se rindió ante vos para honrar al que supo alzar su voz ante las calumnias e injurias que se lanzaban contra España» ${ }^{71}$.

Pereyra era una figura pública muy querida. De hecho, sus libros se utilizaban como textos escolares. Antonio Magariños, Rafael Altamira y Antonio Ballesteros Beretta los recomendaban en sus cursos ${ }^{72}$. Individuos de toda militancia política u orientación intelectual sostenían que las obras de Pereyra

\footnotetext{
69 La Libertad. Diario republicano independiente, 12 de octubre de 1935.

70 Nuevo día: Diario de la provincia de Cáceres, 13 de Octubre de 1926.

71 Idem.

72 Vélez, 2007: 231.
} 
estaban revolucionando la visión de la historia de España que circulaba en los libros tradicionales. Ángel Delgado Alonso, miembro de la Juventud Republicana Cordobesa escribió en el semanario del Partido Republicano Conservador Renovación:

En esta época de inquietud espiritual, con un nuevo concepto de la vida, viene un nuevo concepto de la historia. Carlos Pereyra ha escrito con este criterio una historia, una monografía mejor dicho, de la labor de España en América; es una obra de nuestro tiempo que ha causado una profunda huella, porque gracias a su lectura desaparecieron de mi memoria lecciones arcaicas de los viejos libros de texto. Esta obra descubre algo, que para los estudiantes era un secreto, y que nos muestra cómo en la conquista de América el descubrimiento de Colón es algo sin importancia y más de suerte que de ciencia y de valor; como los reyes incomprensivos hicieron una política contraria al interés nacional, y como el pueblo español, el verdadero pueblo español, realizó la conquista del inmenso continente llegando en pocos años desde la costa hasta el propio corazón ${ }^{73}$.

En este sentido, el propósito de las obras de nuestro autor se extendía más allá de la divulgación. Pereyra se elevó a «maestro» del continente. En el diario La Asunción de Paraguay se lee: «Carlos Pereyra es uno de los maestros más representativos del continente; maestro en toda acepción del vocablo, y uno de los creadores de la "Nueva América" $\gg 74$. El mexicano había dado un paso mayúsculo en la escritura de un tipo de historia útil para activar intercambios fecundos entre la región hispanoamericana. Se estaba comportando como el Pereyra embajador que había sido en otros tiempos, aunque quizá como un embajador «cultural» que vinculó no tanto naciones como espíritus colectivos.

\section{LA GUERRA CIVIL Y LA «HISPANIDAD»}

Pereyra empezó la década de 1930 con nuevos bríos. Podemos calibrar el alcance de su reconocimiento por la aparición de su nombre en la Guía oficial de España, bajo el título de «Señor académico honorario» ${ }^{75}$. A partir de entonces continuó dando conferencias y cursos en varios centros educativos y culturales sobresalientes, como el Ateneo español de Madrid, la Unión Patriótica y el Colegio Vasco de Gama. De hecho, la Sección de Ciencias Históricas del Ateneo lo nombró Presidente y fue acreedor de otros títulos en sociedades

73 Renovación. Semanario del partido Republicano conservador, 2 de marzo de 1933.

74 Dotor, 1948: 151.

75 Guía oficial de España, 1935. 
historiográficas de algunos países. Entre otros, fue nombrado miembro de la Academia Americana de la Historia en Buenos Aires (enero de 1930), y Académico de la Academia Dominicana de la Historia (noviembre de 1934) ${ }^{76}$.

Al vivir en España, nuestro autor padeció la guerra civil. De su experiencia legó una colección de ensayos en clave biográfico-periodística, redactada entre julio de 1939 a noviembre de 1940. Se publicaron en 1946 con el título España está despierta ${ }^{77}$. Ahí, Pereyra habla del hambre y de la violencia. Recuerda haber pasado inviernos sin calefacción, incluso la supresión del desayuno. «Comer era una idea fija. No se pensaba en otra cosa. No se hablaba de otra $\operatorname{cosa}{ }^{78}{ }^{78}$. Es manifiesto su repudio hacia los republicanos, como sus simpatías por los rebeldes y su líder, Francisco Franco. Según Pereyra, los «rojos» habían sido los culpables de la desolación de España.

El autor de La obra de España en América denuncia lo que llamó las «atrocidades» republicanas con lujo de nombres, números y datos construidos bajo su propia observación. En una prosa que recuerda sus ensayos de denuncia a la diplomacia estadounidense, Pereyra no siempre revela el origen de su información. No obstante, es palpable que conoce el funcionamiento político y detalles biográficos de los jefes de policía, soldados, y otros representantes de los sistemas judiciales. Pereyra menciona quiénes habían sido llevados a las cárceles, procesados y eventualmente torturados o asesinados. Parece que él tenía acceso a la documentación de las representaciones diplomáticas, a las confesiones y a ciertos relatos morbosos de lo que sucedía en el interior de las «checas», como se llamaba al sistema carcelario. Es posible que se documentara en la prensa y radio, pero podríamos creer que estuvo en contacto con personas que vivían los acontecimientos en carne propia. En todo caso, el fin de la guerra y el triunfo de las tropas rebeldes significaron un gran alivio para el historiador:

El 28 de marzo de 1939 quedó justificado mi punto de vista. Al desaparecer los jefes de las bandas, Madrid encontró de nuevo su sonrisa, su júbilo, su pulcritud, su gracia y su fe. Era un pueblo que no blasfemaba, que no odiaba, que no hacía recuerdos del mal sino para regocijarse con el bien recuperado ${ }^{79}$.

Pero pocos años antes de esta turbulencia, el clima intelectual estuvo surcado por nuevas interpretaciones sobre el sentido de la identidad española.

\footnotetext{
76 Dotor, 1948: 178.

77 VV. AA., 1946: s/p. En este libro también aparecen contribuciones de los mexicanos Rodolfo Reyes y Alfonso Junco.

78 Idem.

79 Idem.
} 
Desde mediados de los treinta circulaba una fórmula del nacionalismo español conocida como «hispanidad». Esta corriente — si se permite tal calificativosurgió en discursos y folletos de intelectuales españoles católicos. Se atribuye a Zacarías de Vizcarra la invención del concepto y se adjudica al escritor regeneracionista Ramiro de Maeztu su difusión a través de la colección de ensayos Defensa de la hispanidad $(1935)^{80}$. Por otro lado, se reconoce al arzobispo de Toledo, Isidro Gomá y Tomás como impulsor del pensamiento de Maeztu, y como otro ideólogo que acomodó el término en la retórica fascista. En su discurso "Apología de la hispanidad”, Gomá explica la noción:

Es el temperamento español, no el temperamento fisiológico, sino el moral e histórico, que se ha trasfundido a otras razas y a otras naciones y a otras tierras y las ha marcado con el sello del alma española (...) es el genio de España que ha incubado el genio de otras tierras $\mathrm{y}$, sin desnaturalizarlo, lo ha elevado y depurado y lo ha hecho semejante a él ${ }^{81}$.

Cuando la guerra civil terminó, el grupo encabezado por Francisco Franco acogió la retórica de la «hispanidad» ${ }^{82}$. De hecho, algunos de sus tópicos figuraban en los puntos programáticos de Falange Española redactados por Miguel Primo de Rivera. «Tenemos voluntad de imperio. Afirmamos que la plenitud histórica de España es el Imperio (...). Respecto de los países de Hispanoamérica, tendemos a la unificación de cultura, de intereses económicos y de poder. España alega su condición de eje espiritual del mundo hispánico como título de prominencia de las empresas universales» ${ }^{83}$. Para difundir estos principios, el gobierno de Franco lanzó una propaganda organizada que quedó documentada, entre otros, por el trabajo de Eduardo González Calleja La hispanidad como instrumento de combate ${ }^{84}$.

Las ideas de la hispanidad constituyeron la filosofía latente en las relaciones con Hispanoamérica y de las instituciones académicas diseñadas para impulsarlas. Así, en 1940 se fundó en Madrid la Asociación Cultural Hispanoamericana ${ }^{85}$. En noviembre de ese año se creó el Consejo de la Hispanidad, cuya misión sería «Conseguir que España, por su ideal ecuménico, sea para

80 El pensamiento de la hispanidad ha sido tratado por múltiples autores. Podemos mencionar a Sepúlveda, 2005. Rojas Mix, 1991. Colom, 2006. Delgado Gómez-Escalonilla, 1988.

81 Gomá y Tomás, 1935: 327.

${ }^{82}$ La idea de Hispanidad fue retomada por intelectuales fascistas que le asignaron un tono beligerante. Cabe mencionar a Ramiro Ledesma Ramos y su libro La conquista del Estado; y a Onésimo Redondo, a través del semanario Libertad. Véase González Calleja, 1988: 24-27.

83 Citado por González Calleja, 1988: 29.

84 Ibidem: 83.

85 Delgado Gómez-Escalonilla, 1988: 60. 
los pueblos hispanos la representación fiel de esta Europa cabeza del mundo» ${ }^{86}$. En 1942 surgió la Escuela de Estudios Hispanoamericanos de Sevilla, destinada a «formar especialistas en cuestiones americanas» ${ }^{87}$.

Pereyra ingresó dentro de esta nueva red institucional. Desde que se fundó el Consejo Superior de Investigaciones Científicas, el 24 de noviembre de 1939, fue nombrado Jefe de Sección de Conquista y Colonización del Instituto Gonzalo Fernández de Oviedo, — cargo que ocupó entre 1940 y 1942 -, dirigido por el historiador Antonio Ballesteros Beretta. Además, Pereyra continuó publicando en las editoriales América, Saturnino Calleja, Aguilar y Salvat. Formó parte del consejo editorial de la Revista de Indias, órgano de difusión del Instituto, en la que publicó veintidós escritos. Algunos eran reseñas, como las que dedicó a Eduardo Colombres ${ }^{88}$, Roberto Agramonte ${ }^{89}$, y a Julio y Rodolfo Irazusta ${ }^{90}$. Otros eran comentarios de textos, al parecer derivados de otras investigaciones, como "Lutero en el Vaticano"91 o "Postrera voluntad y testamento de Hernando Cortés, marqués del Valle"92. También publicó ensayos anti panamericanistas como "Propaganda roja de barras y estrellas"93, y textos de reivindicación hispanoamericanista como "Restauración de la conciencia unitaria del mundo hispánico"94.

Además de contribuir en revistas académicas, el nombre de Pereyra aparecía muy a menudo en publicaciones político literarias donde brillaba la retórica de la hispanidad. Quizá la más reconocida era Acción española, del partido político del mismo nombre. Esta publicación se planteaba «salvar a España» rechazando la modernidad y la revolución, reivindicando el catolicismo y una monarquía tradicional ${ }^{95}$. Su fundador era el Conde Saltibáñez del Río (también conocido como «Marqués de Quintanar»), apoyado por los «evangelistas de la hispanidad»: Ramiro de Maeztu (quien se convirtió en su director desde el número 38), Zacarías de Vizcarra y el cardenal Isidro Gomá

86 Citado en Ibidem: 63.

87 La Escuela de Estudios Hispanoamericanos de Sevilla se fundó el 10 de noviembre de 1942. En el decreto de fundación se estableció que colaboraría con el Instituto Gonzalo Fernández de Oviedo y con el Instituto Hispano Cubano de Historia de América de Sevilla. “Crónica del mundo hispánico", Revista de Indias, 1943: 189-192.
88 Pereyra, 1941b: 157-158.
89 Pereyra, 1941a: 183-190.
90 Pereyra, 1940a: 205.
91 Pereyra, 1941c: 195-196.
92 Pereyra, 1940b: 208.
93 Pereyra, 1941d: 209-215.
94 Pereyra, 1941e: 194-195.
95 Morodo, 1980. 
y Tomás. José Carlos Mainer, en La edad de plata, describe que en Acción española «no falta el fascismo confeso, los clérigos montaraces hispanos, el teórico de la hispanidad Zacarías de Vizcarra, los militares responsables de la intentona del 10 de agosto de 1932, los generales Sanjurjo y García de la Herrán». Un artículo de esta publicación anuncia el propósito de «invitar cordialmente a la unión leal y franca de todos los españoles que aún sientan el estímulo de sus deberes para con Dios y su patria» ${ }^{96}$.

Algunos escritores de Acción española acudieron a la obra historiográfica de Pereyra buscando argumentos para reforzar el pensamiento de la «hispanidad». Un artículo que hablaba sobre el valor moral de los gobernantes españoles en América, citaba uno de sus textos para justificar la vocación imperial de España: «Un escritor mexicano, D. Carlos Pereyra, ha dicho de nuestros virreyes que "Las repúblicas americanas no han tenido, sino por excepción, gobernantes de la altura moral y de la capacidad práctica demostrada por la mayoría de los virreyes" $\gg{ }^{97}$. Un redactor anónimo que hablaba sobre los atractivos de Sevilla, también hacía hincapié en los trabajos del mexicano: «Y en cuanto a la calidad de la cultura sevillana del siglo XVI básteseme citar el testimonio del ilustre historiador contemporáneo Carlos Pereyra. "El encanto de la civilización hispanoamericana, casi en su totalidad, es obra de la influencia de Sevilla" $\gg{ }^{98}$. El padre Constantino Bayle, en un escrito titulado «España y la educación popular en América», llamaba a Pereyra «el más insigne de los americanistas» ${ }^{99}$.

En el contexto del franquismo, el asunto de la «leyenda negra» ${ }^{100}$ cobró relevancia como parte del nudo ideológico de la «hispanidad». Algunas páginas de Acción española se destinaron a impugnar la «leyenda negra» y encontraron argumentos valiosos en Pereyra. Un artículo titulado "Los derechos del trabajador" cita La obra de España en América para subrayar ciertas «equivocaciones increíbles», atribuidas a historiadores eminentes: «Todo ello

\footnotetext{
96 Acción española, junio de 1934.

97 Acción española, 1 de junio de 1934.

98 Hernández, 1 de marzo de 1933: 662.

99 Acción española, mayo de 1935.

100 El concepto de «leyenda negra» se atribuye al historiador Julián Juderías. Con él se refería a las acusaciones negativas sobre España difundidas en Europa, primordialmente. En sus palabras, se trata de la «leyenda de la España inquisitorial, ignorante, fanática, incapaz de figurar entre los pueblos cultos lo mismo ahora que antes, dispuesta siempre a las represiones violentas, enemiga del progreso y de las innovaciones o, en otros términos, la leyenda que había empezado a difundirse en el siglo XVI a raíz de la reforma, no ha dejado de utilizarse en contra nuestra desde entonces, y más especialmente en momentos críticos de nuestra vida nacional». Juderías, 2014: 102.
} 
repetido, divulgado, gritado por la ignorancia o la aversión de los mediocres, que son en todas partes muchedumbre, el resultado ha sido un juicio errado y calumnioso acerca de la conquista y la colonización española» ${ }^{101}$. El autor remite a Pereyra para llegar a la conclusión de que «al estudiar desinteresadamente y poner la verdad sobre todas las cosas, se llega a la persuasión de la obra admirable que España desarrolló en sus colonias» ${ }^{102}$.

Pero el tema de la leyenda negra rebasaba el dominio literario. Era política, actualidad, y concernía a las publicaciones académicas de interés histórico. Por ejemplo, en la Revista de Estudios Hispánicos, que recopilaba escritos sobre las cosas de América, encontramos un artículo de Roberto Levillier de título "Orígenes, desarrollo y decadencia de la leyenda negra". Ahí escribía: «Me es grato deciros que este movimiento procede principalmente de América, apoyado a la vez de los archivos de este continente y los de España». Mencionaba a Rafael Altamira, Antonio Ballesteros, Américo Castro, Ramón Menéndez Pidal, el padre Constantino Bayle y a Eloy Buyón, entre otros. A su modo de ver, Carlos Pereyra era el «campeón mexicano de la reivindicación de España» ${ }^{103}$.

Ciertas revistas católicas que también alardeaban contra la leyenda negra citaban a Carlos Pereyra. Veintiuno: Revista de pensamiento politico, lo evocó para justificar que los asesinatos cometidos por los españoles en el marco de la conquista habían sido parte de parte de un fenómeno de la época, compartido por otros países. Un artículo de Juan L. Beceiró García titulado "La verdad sobre el genocidio de América", escribe: «Si comparamos la crueldad de los españoles con la de los restantes pueblos, quedamos muy bien situados en relación con ellos (...) Así, Carlos Pereyra nos dice "Cuando Pizarro mataba a Inca Atahualpa, que no era sino un rebelde y un usurpador, sanguinario y fraticida, Enrique VIII de Inglaterra asesinaba a su mujer Ana Bolena y ahorcaba a 72, 000 ingleses católicos" ${ }^{104}$.

Si bien estas revistas manejaban los argumentos de Pereyra para reavivar la hispanidad, Pereyra acudió a estos espacios para criticar la política mexicana. En la revista titulada, justamente, Hispanidad, acusaba a Lázaro Cárdenas por haber afectado a la iglesia católica. «Cárdenas no solo impide la plegaria en las catacumbas nacionalizadas. Se opone, sobre todo, a la enseñanza religiosa, y a la propaganda religiosa, aun cuando estos delitos se so-

\footnotetext{
101 Acción española, 16 de mayo de 1934.

102 Idem.

103 Revista de Estudios Hispánicos, enero de 1935.

104 Veintiuno. Revista de pensamiento político, 22 de junio de 1999.
} 
metan en el fondo de un sótano o de una alcoba de un perito contador» ${ }^{105}$. Las críticas de Pereyra incomodaron a varios mexicanos afiliados al poder. Pero no sabemos qué interés podían tener tales críticas para los lectores españoles. En todo caso, la revista proporcionaba un espacio de expresión del que Pereyra difícilmente podía gozar en su país de origen, en el contexto de la posrevolución.

Otra contribución relevante de Pereyra a la «ideología oficial» española fue su participación en el ciclo de conferencias Voces de la hispanidad. Fueron organizadas por el Consejo de la Hispanidad y transmitidas por la Radio Nacional de España, durante el año de 1940. La conferencia de Pereyra, "El panamericanismo y el momento actual", advertía sobre las ambiciones territoriales estadounidenses. El resto de conferencias fueron dictadas por funcionarios de la Asociación Cultural Hispanoamericana, y de otras instituciones educativas y culturales que pregonaban la hispanidad. Por ejemplo, el Dr. Pío Zabala y Lera, Rector de la Universidad de Madrid y Miembro de la Comisión de Cultura de la Asociación Cultural Hispanoamericana (ACH); Daniel García Mansilla, presidente de ACH; Rodolfo Reyes Ochoa de la Comisión de Cultura de la ACH; Juan Muñoz Reyes, Ministro de Bolivia en España; el general José Millán Astray, de la Junta de Patronato de la Comisión Cultural Hispanoamericana; el Marqués de Lozoya, y otros latinoamericanos vinculados a ésta Asociación.

\section{Pereyra EN LA MEMORIA}

Pereyra falleció el 30 de junio de 1942. Los diarios y revistas abundaron en expresiones de lamento y gratitud. La popularidad del historiador se extendió al momento del funeral, al que acudieron personalidades variopintas del mundo intelectual, político y diplomático. La Revista de Indias dedicó una esquela donde mencionó que a la «piadosa recordación» habían asistido Esteban Bilbao, presidente de las Cortes españolas, Don Antonio Álvarez Vidaurre, Ministro de El Salvador, don Pío Zavala Lera, Rector de la Universidad Central, el Marqués de Saltillo, Decano de la Facultad de Filosofía y Letras de Barcelona, Don Rodolfo Reyes Ochoa, ex ministro mexicano, Don Antonio de la Torre; Don Antonio Ballesteros Beretta, Director del Instituto Gonzalo Fernández de Oviedo; y algunos miembros de la familia Pereyra ${ }^{106}$.

105 Hispanidad. Revista quincenal hispanoamericana de ciencias, artes, literatura, politica historia y economía, 1 de febrero de 1936.

106 Revista de Indias, 1943: 394-396. 
Por su parte, el diario $A B C$ distinguió también la presencia de Manuel Halcón, el Canciller del Consejo de la Hispanidad, el historiador Menéndez Pidal y Adolfo Prieto, miembro de la colonia española en México.

Las esquelas y escritos de homenaje dan a conocer los matices del recuerdo en torno a los aportes de Pereyra. Como medio académico, la Revista de Indias destacó sus virtudes de trabajador. Recordando el último día en que visitó su despacho, en la revista se lee de los trabajos que dejó pendientes: «Abierto quedó sobre su mesa el grueso infolio de las Cartas de Indias» ${ }^{107}$. Gran parte de los diarios manifestaron algún tipo de encomio, y los de orientación católica refrendaron el aporte de Pereyra a la hispanidad, sin faltar el apelativo de «caballero cristiano». En el $A B C$ se lee: «Caballero cristiano, de honradez acrisolada, entusiasta de España y de sus tradiciones, adversario de la intervención norteamericana en los destinos de Hispanoamérica, dedicó gran parte de su vida a exaltar los valores hispanos» ${ }^{108}$. En la revista Alcázar, el escritor Pedro Marroquín expresó: «En Carlos Pereyra no ha muerto solamente un mejicano ilustre, honra y prez de su patria, ni un eminente historiador, ni un notable escritor de relevantes méritos literarios y de prosa castiza y clara. En Carlos Pereyra ha desaparecido, al descender sus restos mortales al sepulcro, un fervoroso enaltecedor y propagandista de las grandezas y glorias pasadas de España» ${ }^{109}$.

En México, Pereyra fue acreedor de amplios elogios, especialmente de personajes afines al hispanismo. Por ejemplo Alfonso Prieto y Alfonso Reyes, quienes asistieron a su funeral. Su coterráneo Miguel Alessio Robles manifestó su pésame, en un momento en que preparaba el septuagésimo aniversario del Ateneo Fuente de Saltillo ${ }^{110}$. Un artículo en el diario Excélsior, cuyo autor no es nombrado, mencionaba: «Pereyra, con valentía, firmeza y aptitud, emprendió la enorme tarea de hacer desvanecer la leyenda negra que flotaba sobre la obra hispana en América» ${ }^{111}$.

Pero si en España Pereyra se recordaba como «caballero de la hispanidad», algunos mexicanos evocaron su apego a su tierra natal. Un artículo en la revista Hoy manifestó que Pereyra «siempre estuvo en correspondencia con sus amigos de México» ${ }^{112}$. El escritor Luis Lara Pardo escribió «Pereyra era un gran mexicano, de los más puros que he conocido. España le había acogido,

\footnotetext{
107 Dotor, 1948: 192.

$108 A B C, 1$ de julio de 1942.

109 Dotor, 1948: 200.

110 Ibidem: 209.

111 Ibidem: 213.

112 Ibidem: 210.
} 
con cariño, y el sentía un gran cariño por España. Pero nunca dejó México de estar en su corazón» ${ }^{113}$. El escritor Nicolás González Ruiz manifestaba que Pereyra era un «enamorado de la historia de la familia de los pueblos hispánicos ${ }^{114}$.

\section{CONSIDERACIONES FINALES}

Carlos Pereyra tendió un puente entre sensibilidades hispanoamericanas diversas. Complació a intelectuales americanos que encontraron en él al enunciador perfecto del reclamo al imperialismo estadounidense. En efecto, su escritura ensayística - enriquecida con el análisis de fuentes y de ricas experiencias diplomáticas - de algún modo lo asemeja a Enrique Rodó, José Martí, Eduardo Prado y a Rufino Blanco Fombona. Aparte de atraer a los hispanoamericanistas militantes, Pereyra encontró a un nutrido nicho de auditores en todos aquellos cautivados por el pensamiento de la hispanidad. Esta ambivalencia, que hizo de la misma persona un intelectual comprometido y un pensador de la «reacción», nos hace pensar en los componentes de la «ecuación Pereyra». Estamos frente a un hispanoamericanista-antiimperialista, que en el ocaso de sus días se concilió con la hispanidad y el nacionalismo español. Esta facultad conciliadora le atrajo aplausos y un lugar privilegiado en instituciones académicas de España. Pero más allá, lo salvó de la suerte que padeció una gran parte de la intelectualidad en este país. Pereyra no volvió a México, como lo hiciera Silvio Zavala, ni debió exiliarse, como su amigo Rafael Altamira ${ }^{115}$.

Las fuentes analizadas sugirieron que el trabajo de Pereyra engarzó perfectamente en el contexto de una España que abría sus puertas hacia sus antiguas colonias, y que impugnaba el intervencionismo estadounidense bajo el recuerdo del año de 1898. Las primeras décadas del siglo XX fueron afortunadas para los interesados en las cosas de América, favorecidos por la modernización del Archivo General de Indias, por sus contactos personales y por la diversificación del mundo editorial. Los trabajos de Pereyra fueron bienvenidos, fue un personaje mediático. Se hizo eco en medios de toda raigambre ideológica, incluyendo periódicos de tendencia republicana y revistas católicas. Su divulgación se prolongó en la radio, en conferencias, pláticas y revis-

113 Ibidem: 214.

114 Ibidem: 216.

115 Lira, 2012. 
tas culturales. Su fama mucho debió también a sus buenas relaciones con las altas esferas de la política y de la cultura.

Reiterando lo que ya otros han dicho, la obra de Pereyra sigue presentado grandes desafíos. Este artículo pretendió ser un avance, pero sobre todo una invitación a la escritura de una biografía. Sus experiencias en México, especialmente en la Escuela Nacional Preparatoria, sus desencuentros con los revolucionarios, su labor como embajador, son temas que quedan pendientes para próximos estudios. Podríamos sumar a la agenda un análisis de sus redes y relaciones personales, de sus trabajos como divulgador. Aparte, queda por evaluar — desde enfoques propiamente historiográficos - sus métodos de trabajo, análisis de fuentes y estilo literario. Estos asuntos contribuirían al estudio de un importante historiador. Pero más allá, podrían ayudarnos a comprender nuevas caras del hispanoamericanismo - en todas sus expresiones humanas y mediáticas - en un momento situado.

\section{BIBLIOGRAFÍA}

Acevedo, Edberto Óscar, "Carlos Pereyra y su pensamiento sobre la emancipación hispanoamericana", Revista de historia americana y argentina, VIII/15-16 (Mendoza, 1970-71): 15.

Acevedo, Edberto Óscar, Carlos Pereyra, historiador de América, Sevilla, Escuela de Estudios Hispano-Americanos, 1986.

Aguayo Spencer, Rafael, Carlos Pereyra, México, Secretaría de Educación Pública, 1948.

Altamira, Rafael, Mi viaje a América, Oviedo, Universidad de Oviedo, 2007. (Primera ed. 1910).

Arenal Fenochio, Jaime del, "Los tres Monroe de Carlos Pereyra", http://biblio.juridicas.unam.mx/libros/4/1855/8.pdf, abierto el 4 de enero de 2015.

Astrana Marín, Luis, Cristóbal Colón: su patria, sus restos y el enigma del descubrimiento de América, Madrid, Voluntad, 1929.

Ballesteros Beretta, Antonio, Cristóbal Colón y el descubrimiento de América, Barcelona/Buenos Aires, Salvat, 1945.

Bravo Ugarte, José, "Carlos Pereyra, el historiador de la hispanoamericanidad", Memorias de la Academia Mexicana de la Historia, 4/3 (México, 1945): 231-253.

Cagiao Vila, Pilar, Rey Tristán, Eduardo y Pérez Santos, Raquel, "Contribuciones intelectuales latinoamericanas en la Revista de Cultura Hispanoamericana de Madrid: Carlos Pereyra", Pilar Cagiao Vila (ed.), De ida y vuelta. América y España: 
los caminos de la cultura, Santiago de Compostela, Universidad de Santiago de Compostela, 2007: 309-320.

Colom González, Francisco, El altar y el trono: ensayos sobre el catolicismo politico iberoamericano, Barcelona, Anthropos, 2006.

Delgado Gómez-Escalonilla, Lorenzo, Diplomacia franquista y política cultural hacia Iberoamérica, 1939-1953, Madrid, CSIC, 1988.

Dotor, Ángel, Carlos Pereyra, Madrid, Aguilar, 1948.

Dumas, Claude, Justo Sierra y el México de su tiempo, 1848-1912, tomo II, México, Universidad Nacional Autónoma de México, 1992,

Garrido, Luis, Carlos Pereyra, México, Botas, 1969.

Gomá y Tomás, Isidro, “Apología de la hispanidad”, Ramiro de Maeztu, Defensa de la hispanidad, Madrid, Gráfica Universal, 1935: 327.

González Calleja, Eduardo, La hispanidad como instrumento de combate: raza e imperio en la prensa franquista durante la guerra civil española, Madrid, CSIC, 1988.

Granados, Aimer, Debates sobre España. El hispanoamericanismo en México a fines del siglo XIX, México, El Colegio de México/Universidad Autónoma Metropolitana, 2005.

Guía Oficial de España, Madrid, 1935.

Hale, Charles, La transformación del liberalismo en México a fines del siglo XIX, México, Vuelta, 1991.

Hernández Díaz, José, “Comentarios en torno a la figura del escultor Juan de Mesa. 1583-1627. Por José Hernández Díaz, Sevilla, 1933”, Acción española, IV/24 (Madrid, 1 de marzo de 1933): 660- 663.

Iduarte, Andrés, Pláticas hispanoamericanas, México, Tezontle, 1951.

Juderías, Julián, Leyenda negra, Madrid, La esfera de los libros, 2014.

Kozel, Andrés y Montiel, Sandra, "Carlos Pereyra y el mito de Monroe", Alexandra Pita y Carlos Marichal, Pensar el antiimperialismo: Ensayos de historia intelectual latinoamericana, 1900- 1930, México, El Colegio de México/Universidad de Colima, 2012: 69-100.

Krauel, Javier, Imperial emotions. Cultural responses to myths of empire in fin de siècle Spain, Liverpool, Liverpool University Press, 2013.

Labra, Rafael María de, El Ateneo de Madrid, 1835-1905, Madrid, 1906.

Laín Entralgo, Pedro, España como problema, Barcelona, Galaxia Gutenberg, 2005.

Lira, Andrés, Exilio político y gratitud intelectual. Rafael Altamira en el archivo de Silvio Zavala (1937-1946), México, El Colegio de México, 2012. 
Lobjeois, Eric y Lida, Clara, México y España en el primer franquismo, 1939-1950: rupturas formales, relaciones oficiosas, México, El Colegio de México, 2001.

Maeztu, Ramiro de, Defensa de la hispanidad, Madrid, Gráfica Universal, 1935.

Mainer, Carlos, La edad de plata (1902-1939): ensayo de interpretación de un proceso cultural, Madrid, Cátedra, 1999.

Morodo, Raúl, Acción española. Orígenes ideológicos del franquismo, Madrid, Tucar ediciones, 1980.

Pereira Castañares, Juan Carlos, "Primo de Rivera y la diplomacia española en Hispanoamérica: El Instrumento de un objetivo", Quinto Centenario, 10 (Madrid, 1986): 131-156.

Pereyra, Carlos, De Barradas a Baudin. Un libro de polémica histórica, México, Tipografía económica, 1904a.

Pereyra, Carlos, Juárez discutido como dictador y estadista: a propósito de los errores, paradojas y fantasías del Sr. Don Francisco Bulnes, México, Tipográfica Económica, 1904b.

Pereyra, Carlos, El mito de Monroe, Madrid, América, 1916.

Pereyra, Carlos, La huella de los conquistadores, Madrid, Aguilar, 1929.

Pereyra, Carlos, Breve historia de América, Madrid, Aguilar, 1930.

Pereyra, Carlos, "Irazusta, Rodolfo, Irazusta Julio, 'La Argentina y el imperialismo británico. Los eslabones de una cadena, 1806-1833'”, Revista de Indias, I/1 (Madrid, 1940a): 205.

Pereyra, Carlos, "Postrera voluntad y testamento de Hernando Cortés, Marqués del Valle de México", Revista de Indias, I/1 (Madrid, 1940b): 208.

Pereyra, Carlos, "Agramonte, Roberto, "Biografía del dictador García Moreno"”, Revista de Indias, II/6 (Madrid, 1941a): 183-190.

Pereyra, Carlos, “Colombres, Eduardo L.: San Martín y Bolívar en la entrevista de Guayaquil a la luz de nuevos documentos definitivos (Buenos Aires, 1940)", Revista de Indias, II/3 (Madrid, 1941b): 157-158.

Pereyra, Carlos, "Lutero en el Vaticano", Revista de Indias, II/4 (Madrid, 1941c): 195-196.

Pereyra, Carlos, "Propaganda roja de barras y estrellas", Revista de Indias, II/4 (Madrid 1941d): 209-215.

Pereyra, Carlos, "Restauración de la conciencia unitaria del mundo hispánico", Revista de Indias, II/4 (Madrid 1941e): 194-195.

Pereyra, Carlos, Obras completas (prólogo de Manuel González Ramírez), México, Libreros Mexicanos Unidos, 1959. 
Pereyra, Carlos, La obra de España en América/La conquista de las rutas oceánicas (prólogo de Silvio Zavala), México, Porrúa, 1986. (Primera ed. 1923).

Pita González, Alexandra y Marichal Salinas, Carlos, Pensar el antiimperialismo. Ensayos de historia intelectual latinoamericana, 1900-1930, México, El Colegio de México/Universidad de Colima, 2012.

Quirarte, Martín, Carlos Pereyra, caballero andante de la historia, México, Instituto de Historia, 1952.

Revel, Jacques, Un momento historiográfico. Trece ensayos de historia social, Buenos Aires, Manantial, 2005.

Rojas Mix, Miguel, Los cien nombres de América: eso que descubrió Colón, Barcelona, Lumen, 1991.

Segnini, Yolanda, La editorial América de Rufino Blanco-Fombona: Madrid 19151933, Madrid, Libris, Asociación de Libreros de Viejo, 2000.

Sepúlveda, Isidro, El sueño de la madre patria. Hispanoamericanismo y nacionalismo, Madrid, Fundación Carolina, 2005.

Shaw, Donald, La generación del 98, Madrid, Cátedra, 1985.

Sierra, Justo, México, su evolución social, México, Editorial J. Ballescá y compañía, 1900.

Vélez, Palmira, La historiografía americanista en España, 1755-1936, Madrid/Frankfurt, Iberoamericana/Vervuert, 2007.

VV. AA., Voces de hispanidad, Ciclo de conferencias organizado por la Asociación Cultural Hispanoamericana, emitido por la Radio Nacional de España a los pueblos de América, Madrid, Gráficas Afrodisio Aguado, 1940.

VV. AA., España está despierta (Recopilación), México, s. n., 1946.

Fecha de recepción: 20 de octubre de 2015.

Fecha de aceptación: 18 de febrero de 2016. 


\section{On Americanist historiography and a "caballero de la hispanidad": Carlos Pereyra in Spain (1916-1942)}

This article analyses the final years of Carlos Pereyra in Spain (1916 to 1942). Our aim is to understand the strategies he used to become an integral part of Spanish cultural life and one of the most renowned Americanists. We investigate his career, his political thinking, his personal relationships, his writings, and his contributions to cultural events. Sources include biographies, magazines, journals, bibliography, and his authored works.

KEY WORDS: Hispano-Americanism; Americanism; Hispanidad; anti-imperialism; Historiography; intellectual history; intellectual networks. 